\title{
Can the Markov switching model forecast exchange rates?
}

\author{
Charles Engel* \\ Department of Economics, University of Washington, Seattle, WA 98195, USA \\ National Bureau of Economic Research, Cambridge, MA 02138, USA
}

Received September 1991, revised version received March 1993

A Markov-switching model is fit for 18 exchange rates at quarterly frequencies. The model fits well in-sample for many exchange rates. By the mean-squared-error criterion, the Markov model does not generate superior forecasts to a random walk or the forward rate. There appears to be some evidence that the forecasts of the Markov model are superior at predicting the direction of change of the exchange rate.

\section{Introduction}

The behavior of the dollar against certain currencies appears to be forecastable. In particular, the exchange rate appears to follow long swings it drifts upward for a considerable period of time, and then switches to a long period with downward drift. Engel and Hamilton (1990) found that the dollar/mark, dollar/pound and dollar/French franc exchange rates can be described well by Hamilton's (1989) Markov switching model.

This paper investigates whether the Markov switching model is a useful tool for describing the behavior of floating exchange rates more generally. The time-series properties of 18 exchange rates in the post-Bretton Woods period, including 11 non-U.S. dollar exchange rates, are investigated. In general, the model of Engel and Hamilton (EH) does not clearly outperform the random walk model or the forward exchange rate in out-of-sample forecasts. The mean squared errors of the forecasts of the segmented trends model tend not to be significantly lower than those of a zero-drift random walk, a random walk with drift or the forward rate. There is some evidence,

Correspondence to: Charles Engel, Department of Economics, University of Washington, Seattle, WA 98195, USA.

*I wish to thank Frank Diebold and Jim Hamilton for useful suggestions. Much of the work for this paper was completed while I was a Visiting Scholar at the Federal Reserve Bank of Kansas City. The views expressed in this paper are not necessarily those of the Federal Reserve Bank of Kansas City or the Federal Reserve System. 
however, that the segmented trends model is superior to its competitors in forecasting the direction of change of exchange rates.

The paper focuses on exchange rates that are measured at the end of each quarter. The estimation period is 1973-1986, and the post-sample forecast period is $1986-1991$.

There is no natural frequency to measure changes in exchange rates. If the exchange rate process follows a two-state Markov switching process on monthly data, for example, it will not generally then also follow a two-state Markov switching process on quarterly data, and vice versa. So, the models were also estimated on monthly data. The general conclusions about the forecasting ability of the segmented trends model was not affected by the choice of estimation period, but the model estimated on quarterly data does seem to perform better in-sample than the monthly model. For space considerations, the results of the monthly exercise are not included [see Engel (1992)].

Section 2 reviews briefly the Markov switching model, and techniques for estimation. Section 3 presents estimates of the model on quarterly changes in logs of cxchange rates. Section 4 discusses criteria for evaluating the forecasting performance of the model. Section 5 presents the results of the forecasting contest between the Markov switching model, the random walk with and without drift and the forward exchange rate. Section 6 concludes the paper by speculating on the meaning of the less than spectacular forecasting performance of the Markov switching model.

\section{The model and its estimation}

This section outlines the Markov switching model. An excellent survey is available in Hamilton (1991).

Changes in the $\log$ of the exchange ratc are distributed normally with mean $\mu_{i}$ and variance $\sigma_{i}^{2}$ in each of two possible states of the world $(i=1,2)$. The state at time $t$ is determined randomly, and depends only on the state at time $t-1$. The probability of being in state $i$ at time $t$ if the exchange rate were in state $i$ at time $t-1$ is $p_{i}$.

This is a simple version of the more general Markov switching model described by Hamilton $(1989,1991)$. The exchange rate could be allowed to follow more general stochastic processes in each state. There can be more than two states. The $p_{i}$ could vary over time. Moreover, the exchange rate need not be modeled as a univariate process. It could be one element of a multivariate Markov switching process.

The simple univariate model described above, in which the log of the exchange rate follows a random walk with drift in each of two states (the segmented trends model), was found by EH to provide a good description of exchange rate behavior. It outperformed a random walk both in-sample and 
out-of-sample. The model still allows a variety of behavior in the time series of exchange rates. In particular, large values of the $p_{i}$ generate the 'long swings' in exchange rates which EH argue are characteristic of dollar exchange rates. Furthermore, the parsimony of the parameterization (only six parameters need to be estimated for each exchange rate: $\mu_{i}, \sigma_{i}$ and $p_{i}, i=1,2$ ) promises good forecasting properties for the model.

The parameter vector $0=\left(\mu_{1}, \mu_{2}, \sigma_{1}, \sigma_{2}, p_{1}, p_{2}\right)$ can be estimated by maximum likelihood methods. The sample likelihood is a function of the observed values of the changes in the logs of exchange rates. The states $\left(s_{1}, s_{2}, \ldots, s_{T}\right)$ are unobserved, and the econometrician must draw inferences about the probability of $s_{t}=1$ or 2 based on the observed data.

The maximum likelihood estimation in this paper is performed using the EM algorithm described by Hamilton (1990).

\section{Estimates on quarterly data}

This section investigates the behavior of the U.S. dollar exchange rate relative to the Japanese yen, the U.K. pound, the Canadian dollar, the Italian lira, the French franc, the Swiss franc and the German mark; and the behavior of the yen and pound against the remaining currencies. The exchange rate changes are measured on a quarterly basis in this section.

The data were compiled by Data Resource Inc., and measured as the average of the bid and ask rates on the last day of the period. The log changes are multiplied by 100 to express things in percentage terms.

The first observation is for the second quarter of 1973, so the first quarterly change is observed at the end of the third quarter of that year. The model is estimated through the first quarter of 1986.

Estimates are reported in table 1. The maximum likelihood estimates show that the two states generally differ not only in mean, but in variance as well. (The standard errors of the coefficient estimates are reported in parentheses.) For many of the currencies, there seems to be evidence of long swings in the exchange rate. That is, the probability of staying in a state once you are in it $\left(p_{i}\right)$ is large. This seems to be true for all U.S. dollar exchange rates except for the U.S. dollar/Canadian dollar rate, for all yen rates, and for the pound/ Canadian dollar rate. On the other hand, the exchange rates for those countries that are in close geographical proximity - the U.S. dollar/Canadian dollar and the pound against European currencies - show much lower $p_{i}$. [See Engel (1992) for a discussion of the properties of the many local maxima that arise in the estimation of the Markov model.]

EH note that while a simple random walk is nested in the segmented trends model $\left[\left(\mu_{1}=\mu_{2}\right)\right.$ and $\left.\left(\sigma_{1}=\sigma_{2}\right)\right]$, under the null hypothesis two problems arise that invalidate the usual approaches for establishing asymptotically consistent tests of that null. The first is that under the null, $p_{1}$ and $p_{2}$ 
Table 1

Parameter estimates for segmented trends model.

Quarterly, 1973:3-1986:1

\begin{tabular}{|c|c|c|c|c|c|c|}
\hline Currency & $\mu_{1}$ & $\mu_{2}$ & $p_{1}$ & $p_{2}$ & $\sigma_{1}^{2}$ & $\sigma_{2}^{2}$ \\
\hline USCA & $\begin{array}{c}-0.81297 \\
(0.40800)\end{array}$ & $\begin{array}{c}-0.21505 \\
(0.39907)\end{array}$ & $\begin{array}{c}0.710930 \\
(0.200119)\end{array}$ & $\begin{array}{c}0.163457 \\
(0.361071)\end{array}$ & $\begin{array}{c}5.33011 \\
(1.50279)\end{array}$ & $\begin{array}{c}0.68901 \\
(0.51157)\end{array}$ \\
\hline USFR & $\begin{array}{c}3.20287 \\
(1.01668)\end{array}$ & $\begin{array}{c}-3.69747 \\
(1.23946)\end{array}$ & $\begin{array}{c}0.821723 \\
(0.120082)\end{array}$ & $\begin{array}{c}0.885774 \\
(0.079598)\end{array}$ & $\begin{array}{l}10.9337 \\
(4.07552)\end{array}$ & $\begin{array}{l}28.6117 \\
(8.40175)\end{array}$ \\
\hline USIT & $\begin{array}{c}0.42973 \\
(0.54709)\end{array}$ & $\begin{array}{c}-2.96907 \\
(1.06553)\end{array}$ & $\begin{array}{c}0.866254 \\
(0.108056)\end{array}$ & $\begin{array}{c}0.954205 \\
(0.052007)\end{array}$ & $\begin{array}{c}3.12269 \\
(1.26906)\end{array}$ & $\begin{array}{l}37.0035 \\
(8.96167)\end{array}$ \\
\hline USJA & $\begin{array}{c}-1.46271 \\
(0.90233)\end{array}$ & $\begin{array}{c}9.19055 \\
(3.04496)\end{array}$ & $\begin{array}{c}0.893270 \\
(0.064839)\end{array}$ & $\begin{array}{c}0.613107 \\
(0.195890)\end{array}$ & $\begin{array}{l}14.3615 \\
(3.97635)\end{array}$ & $\begin{array}{c}11.4970 \\
(13.2517)\end{array}$ \\
\hline USSW & $\begin{array}{c}2.20500 \\
(1.25306)\end{array}$ & $\begin{array}{r}-6.09130 \\
(1.20831)\end{array}$ & $\begin{array}{c}0.894640 \\
(0.075991)\end{array}$ & $\begin{array}{c}0.491165 \\
(0.219126)\end{array}$ & $\begin{array}{c}45.5362 \\
(10.2276)\end{array}$ & $\begin{array}{c}4.46869 \\
(3.29118)\end{array}$ \\
\hline USUK & $\begin{array}{c}2.64354 \\
(0.82392)\end{array}$ & $\begin{array}{c}-3.81335 \\
(1.07884)\end{array}$ & $\begin{array}{c}0.892561 \\
(0.085266)\end{array}$ & $\begin{array}{c}0.919611 \\
(0.071844)\end{array}$ & $\begin{array}{l}10.6791 \\
(3.54918)\end{array}$ & $\begin{array}{l}19.6765 \\
(5.63793)\end{array}$ \\
\hline USWG & $\begin{array}{c}3.25496 \\
(1.23438)\end{array}$ & $\begin{array}{c}-1.52475 \\
(1.60705)\end{array}$ & $\begin{array}{c}0.859764 \\
(0.136305)\end{array}$ & $\begin{array}{c}0.928004 \\
(0.090800)\end{array}$ & $\begin{array}{l}15.8625 \\
(7.39103)\end{array}$ & $\begin{array}{c}38.9234 \\
(10.5356)\end{array}$ \\
\hline JACA & $\begin{array}{c}8.77097 \\
(1.60512)\end{array}$ & $\begin{array}{c}-1.57612 \\
(0.78973)\end{array}$ & $\begin{array}{c}0.704687 \\
(0.150420)\end{array}$ & $\begin{array}{c}0.875286 \\
(0.646017)\end{array}$ & $\begin{array}{l}13.5429 \\
(7.47560)\end{array}$ & $\begin{array}{l}14.0444 \\
(3.94569)\end{array}$ \\
\hline JAFR & $\begin{array}{c}3.58878 \\
(0.61267)\end{array}$ & $\begin{array}{c}-5.51198 \\
(0.73186)\end{array}$ & $\begin{array}{c}0.940906 \\
(0.042641)\end{array}$ & $\begin{array}{c}0.731959 \\
(0.151683)\end{array}$ & $\begin{array}{l}13.5845 \\
(3.26396)\end{array}$ & $\begin{array}{c}4.52678 \\
(2.12485)\end{array}$ \\
\hline $\mathrm{JAIT}$ & $\begin{array}{c}-5.30669 \\
(0.93512)\end{array}$ & $\begin{array}{c}3.56015 \\
(0.74361)\end{array}$ & $\begin{array}{c}0.733310 \\
(0.214448)\end{array}$ & $\begin{array}{c}0.972229 \\
(0.028113)\end{array}$ & $\begin{array}{c}2.79205 \\
(2.00113)\end{array}$ & $\begin{array}{l}23.9144 \\
(5.05191)\end{array}$ \\
\hline JASW & $\begin{array}{c}1.99968 \\
(0.59900)\end{array}$ & $\begin{array}{c}-0.85551 \\
(0.98371)\end{array}$ & $\begin{array}{c}0.960745 \\
(0.052939)\end{array}$ & $\begin{array}{c}0.975514 \\
(0.027275)\end{array}$ & $\begin{array}{c}4.80924 \\
(1.99166)\end{array}$ & $\begin{array}{l}34.2684 \\
(8.07182)\end{array}$ \\
\hline JAUK & $\begin{array}{r}-4.33880 \\
(1.51176)\end{array}$ & $\begin{array}{c}4.03509 \\
(1.37454)\end{array}$ & $\begin{array}{c}0.659601 \\
(0.150418)\end{array}$ & $\begin{array}{c}0.886454 \\
(0.095993)\end{array}$ & $\begin{array}{c}8.53950 \\
(3.93052)\end{array}$ & $\begin{array}{l}19.1604 \\
(6.39424)\end{array}$ \\
\hline JAWG & $\begin{array}{c}1.51739 \\
(0.70844)\end{array}$ & $\begin{array}{c}-6.90914 \\
(1.01764)\end{array}$ & $\begin{array}{c}0.974017 \\
(0.027176)\end{array}$ & $\begin{array}{c}0.736699 \\
(0.216006)\end{array}$ & $\begin{array}{l}21.4477 \\
(4.68867)\end{array}$ & $\begin{array}{c}4.51320 \\
(3.16459)\end{array}$ \\
\hline UKCA & $\begin{array}{c}2.52869 \\
(0.66632)\end{array}$ & $\begin{array}{c}-6.85585 \\
(0.70796)\end{array}$ & $\begin{array}{c}0.853455 \\
(0.062965)\end{array}$ & $\begin{array}{c}0.693462 \\
(0.125515)\end{array}$ & $\begin{array}{l}12.9848 \\
(3.48845)\end{array}$ & $\begin{array}{c}6.49192 \\
(2.59656)\end{array}$ \\
\hline UKFR & $\begin{array}{c}0.98397 \\
(0.88491)\end{array}$ & $\begin{array}{c}-5.59244 \\
(8.02732)\end{array}$ & $\begin{array}{c}0.819681 \\
(0.322459)\end{array}$ & $\begin{array}{l}0 \\
-\end{array}$ & $\begin{array}{l}15.8641 \\
(4.47681)\end{array}$ & $\begin{array}{c}26.5625 \\
(35.4442)\end{array}$ \\
\hline UKIT & $\begin{array}{c}0.57283 \\
(0.93841)\end{array}$ & $\begin{array}{c}1.91421 \\
(0.95555)\end{array}$ & $\begin{array}{c}0.784616 \\
(0.171082)\end{array}$ & $\begin{array}{c}0.276690 \\
(0.322431)\end{array}$ & $\begin{array}{l}31.3830 \\
(8.57979)\end{array}$ & $\begin{array}{c}2.61992 \\
(2.37041)\end{array}$ \\
\hline UKSW & $\begin{array}{c}-2.63951 \\
(1.01336)\end{array}$ & $\begin{array}{c}3.03195 \\
(1.28425)\end{array}$ & $\begin{array}{c}0.846922 \\
(0.114527)\end{array}$ & $\begin{array}{l}0 \\
-\end{array}$ & $\begin{array}{l}35.0052 \\
(7.77181)\end{array}$ & $\begin{array}{c}1.98700 \\
(2.85848)\end{array}$ \\
\hline UKWG & $\begin{array}{c}-1.44420 \\
(0.83510)\end{array}$ & $\begin{array}{c}0.29711 \\
(0.38260)\end{array}$ & $\begin{array}{c}0.864952 \\
(0.081470)\end{array}$ & $\begin{array}{c}0.298741 \\
(0.243325)\end{array}$ & $\begin{array}{l}28.9078 \\
(6.54449)\end{array}$ & $\begin{array}{c}0.57115 \\
(0.51855)\end{array}$ \\
\hline
\end{tabular}


Table 2

Wald tests of Markov switching model (chi-square(1) statistics). Quarterly, 1973:3-1986:1

\begin{tabular}{lcr} 
& \multicolumn{2}{l}{ Null } \\
\cline { 2 - 3 } Currency & $p_{1}+p_{2}=1$ & $\mu_{1}=\mu_{2}$ \\
\hline USCA & 0.104 & 0.910 \\
USFR & 17.735 & 21.180 \\
USIT & 34.145 & 7.777 \\
USJA & 6.675 & 18.023 \\
USSW & 2.584 & 26.893 \\
USUK & 36.161 & 29.288 \\
USWG & 15.518 & 4.858 \\
JACA & 11.200 & 51.792 \\
JAFR & 16.135 & 100.724 \\
JAIT & 10.179 & 61.768 \\
JASW & 189.890 & 6.038 \\
JAUK & 8.993 & 49.467 \\
JAWG & 9.982 & 45.255 \\
UKCA & 13.910 & 106.691 \\
UKFR & - & 0.705 \\
UKIT & 0.026 & 0.867 \\
UKSW & & 11.190 \\
UKWG & 0.378 & 3.461 \\
\hline
\end{tabular}

are not identified. The second is that the derivative of the likelihood with respect to $\mu_{i}$ and $\sigma_{i}$ is identically zero under the null hypothesis. EH suggest two other possible null hypotheses. Each represents a stochastic process which in turn nests the random walk.

The first is simply $\mu_{1}=\mu_{2}$. Under this null hypothesis, the two states are different only by their variances, so the exchange rate essentially follows a random walk with heteroskedastic errors. Tests of this hypothesis are reported in table 2. The null can be rejected at the 5 percent level for all currencies of countries not in close geographic proximity. It cannot be rejected for any others except the pound/Swiss franc rate. (The 5 percent critical value is 3.84 .)

The second null proposed by EH is $p_{1}+p_{2}=1$, so that the distribution of $s_{t}$ is independent of $s_{t-1}$. EH note that large values of $p_{1}$ and $p_{2}$ result in exchange rate movements that are characterized by long swings. They strongly reject $p_{1}+p_{2}=1$ in favor of the segmented trends model for the U.S. dollar against the French franc, English pound and German mark. Table 2 shows that the null hypothesis of $p_{1}+p_{2}=1$ is indeed rejected for those three currencies. In fact, it is rejected at the 5 percent level for the exchange rates of all countries that are not in close proximity, with the exception of the dollar/Swiss franc rate. It is not rejected for any of those countries which are neighbors. 
The conclusion that can be reached here is that the segmented trends model fits well in-sample for the 13 exchange rates of non-neighboring countries. In particular, it must outperform a random walk because it outperforms generalizations of the random walk. In section 5 we will consider the forecasting ability of the segmented trends model for these 13 exchange rates.

\section{Standards for measuring forecastability}

We would like to know whether the Markov switching model forecasts well out-of-sample. To a large extent, the question is a relative one: Does the model do well compared with some alternative? A minimal standard would be that the model forecast better than some naive alternative, such as a random walk.

This is precisely the standard used by Meese and Rogoff (1983) in their famous paper which found that virtually no economic model of the excharige rate could outforecast a zero-drift random walk. Since that paper appeared, many authors have used the zero-drift random walk specification as the standard for comparison in measuring forecasting performance [see, for example, Diebold and Nason (1990)].

Engel and Hamilton (1990) argue that the random walk with drift is a more reasonable standard of comparison when the drift term is estimated to be significantly different from zero. Indeed, suppose the drift term is significant within sample, but by some measure the driftless random walk outperforms the random walk with drift in the out-of-sample period. That suggests that the data-generating process in the post-sample period is no longer a random walk with the same drift term as in-sample. In fact, if the data-generating process has switched from a random walk with drift to a driftless random walk - and if the underlying state (drift or no drift) switches according to a Markov process - then the exchange rate can be described exactly by the segmented trends model.

So, first, if the drift is significant in-sample, then the appropriate out-ofsample standard is the random walk with drift. While for a particular sample the zero-drift random walk may perform better out-of-sample, one must avoid the fallacy of choosing the out-of-sample standard based on its out-ofsample performance. Second, if the zero-drift random walk does significantly outperform the random walk with drift out-of-sample (but the drift term was significant in-sample), there is prima facie evidence that the exchange rate can be described by a model similar to the segmented trends model.

One of the purposes of this section of the paper is to determine whether the random walk with drift or the driftless random walk is the appropriate standard. The first column of table 3 presents $t$-statistics for the test of whether the mean change in the log of the exchange rate is zero for quarterly 
Table 3

Tests of significance of drift terms.

Quarterly, 1973:3-1986:1 vs. 1986:2-1991:1

\begin{tabular}{lrll} 
& \multicolumn{1}{c}{ Null } & & \\
Currency & \multicolumn{1}{c}{$\mu_{1}=0$} & $\mu_{1}=\mu_{2}, \sigma_{1}^{2}=\sigma_{2}^{2}$ & $\mu_{1}=\mu_{2}$ \\
\hline USFR & -1.32 & 1.80 & 1.69 \\
USIT & -2.59 & 4.18 & 3.98 \\
USJA & 0.91 & 0.09 & 0.07 \\
USSW & 0.79 & 0.15 & 0.13 \\
USUK & -1.53 & 1.73 & 1.48 \\
USWG & 0.07 & 0.86 & 0.76 \\
JACA & 1.65 & 0.46 & 0.41 \\
JAFR & 2.56 & 1.52 & 1.49 \\
JAIT & 3.59 & 3.47 & 3.77 \\
JASW & -0.06 & 0.03 & 0.03 \\
JAUK & 2.38 & 1.10 & 1.30 \\
JAWG & 0.94 & 0.65 & 0.66 \\
UKCA & -0.58 & 0.05 & 0.05
\end{tabular}

(Statistics in the first column have $t(50$ d.f.) distributions, and those in the second two columns have $x^{\prime}$ (1 d.f.) distributions.)

data from 1973:3 to 1986:1. The mean is significant at the 5 percent level for only four of the 13 exchange rates, and at the 10 percent level for only one additional rate. The second and third columns of table 3 show LM tests for the hypothesis that the mean of the change in the log of the exchange rate changed from the 1973:3-1986:1 to the 1986:2-1991:1 period, under the normality assumption. The first column performs the test assuming equal variances in the two periods, and the second assumes different variances. In both sets of tests the null of the same mean drift is rejected only for the dollar/lira rate at the 5 percent level (although the yen/lira statistic is very nearly large enough to reject at this level). The evidence from table 3 is that it probably does not make much difference whether the random walk with drift or the driftless random walk is used as the standard for out-of-sample forecasting. This conclusion will be further supported shortly by evidence on the out-of-sample forecasting properties of these two alternatives.

We will also compare the forecasting ability of the Markov model with that of the forward exchange rate. Under some assumptions - for example, if there are risk-neutral speculators and markets are efficient - the forward rate should be the best possible predictor of the future exchange rate. So, it is a natural standard of comparison.

Once we decide on the alternative with which to compare the Markov switching model, we must decide what measure of forecasting ability is best. The most frequently used measure is the mean squared error of the forecasts. Using this measure implies that the forecaster has a quadratic loss function 
defined over the forecasts. It is, however, difficult to justify such a loss function on the basis of a particular economic decision facing some individual. From an economist's standpoint, a more reasonable approach would be to postulate some objective for an economic agent, and then measure the value of different forecasts in terms of achieving the maximum of that objective. For example, West et al. (1992) assume that agents wish to choose consumption levels and asset shares at cach point in time to maximize a function of the mean and variance of next period's wealth.

Rather than undertake the difficult exercise of West et al., we look at a few different measures of forecasting ability. The forecasts are judged on the basis of their ability to minimize the mean squared forecast error and by their ability to predict the direction of change of the exchange rate. Engel (1992) also uses the mean absolute forecast error criterion, although there is essentially no difference in the conclusions using this criterion versus the mean squared errors.

One argument for looking at the direction of change of the exchange rate is that it may actually not be a bad proxy for a utility-based measure of forecasting performance. Leitch and Tanner (1991) find that the direction of change criterion is the best proxy among several (including mean squared error and mean absolute error) for choosing forecasts of interest rates on their ability to maximize expected trading profits. It is also possible to think of important circumstances under which the direction of change criterion is exactly the right one for maximizing the welfare of the forecaster. One example is that central banks under pegged exchange rate systems often are interested only in the direction of change in the exchange rate. They might need to intervene to support the currency if it is expected to depreciate, regardless of the size of the expected depreciation.

Table 4 compares the forecasts of the random walk with drift with the random walk with zero drift. For each of the 13 exchange rates, table 4 reports the mean squared error of forecasts for one-, two- and four-quarter changes in the exchange rate over the 1986:2-1991:1 period. The random walk with drift is the better forecaster at all horizons for the dollar/yen, dollar/Swiss franc, dollar/mark, and yen/Swiss franc exchange rates. The zero drift random walk is better for all horizons for the other nine exchange rates.

Simply comparing the values of the mean squared forecast errors does not give us any idea of the significance of the difference. Diebold and Mariano (1991) proposed a statistic for comparing forecasts that is asymptotically $\mathrm{N}(0,1)$. It can be used in our context to test whether the mean squared error of one forecast is better than another.

Table 5 reports the Diebold-Mariano statistics. At the one-month horizon, the difference in the mean squared error is not significant at the 10 percent level for any exchange rate. At the two-quarter horizon, the zero-drift random walk has a significantly lower mean squared error only for the 
lable 4

Post-sample mean squared forecast errors (estimated quarterly, 1973:3-1986:1; forecast 1986:2-1991:1).

\begin{tabular}{|c|c|c|c|c|}
\hline \multirow[b]{2}{*}{ Currency } & \multirow[b]{2}{*}{ Model } & \multicolumn{3}{|c|}{ Horizon } \\
\hline & & 1 & 2 & 4 \\
\hline USFR & $\begin{array}{l}\text { Random walk } \\
\text { RW-0 mean } \\
\text { Forward rate } \\
\text { Markov model }\end{array}$ & $\begin{array}{l}43.83 \\
40.39 \\
41.45 \\
40.12\end{array}$ & $\begin{array}{l}97.69 \\
81.08 \\
86.14 \\
84.09\end{array}$ & $\begin{array}{l}202.32 \\
138.01 \\
154.01 \\
158.28\end{array}$ \\
\hline USIT & $\begin{array}{l}\text { Random walk } \\
\text { RW-0 mean } \\
\text { Forward rate } \\
\text { Markov model }\end{array}$ & $\begin{array}{l}46.74 \\
38.14 \\
42.16 \\
50.41\end{array}$ & $\begin{array}{r}114.09 \\
76.78 \\
92.27 \\
129.97\end{array}$ & $\begin{array}{l}250.90 \\
112.76 \\
170.44 \\
313.30\end{array}$ \\
\hline USJA & $\begin{array}{l}\text { Random walk } \\
\text { RW-0 mean } \\
\text { Forward rate } \\
\text { Markov model }\end{array}$ & $\begin{array}{l}48.80 \\
50.04 \\
49.81 \\
53.58\end{array}$ & $\begin{array}{r}95.99 \\
100.47 \\
101.06 \\
117.01\end{array}$ & $\begin{array}{l}138.19 \\
149.64 \\
159.64 \\
135.04\end{array}$ \\
\hline USSW & $\begin{array}{l}\text { Random walk } \\
\text { RW 0 mean } \\
\text { Forward rate } \\
\text { Markov model }\end{array}$ & $\begin{array}{l}57.09 \\
58.83 \\
58.81 \\
55.34\end{array}$ & $\begin{array}{l}110.63 \\
118.76 \\
120.24 \\
103.16\end{array}$ & $\begin{array}{l}190.63 \\
217.92 \\
222.17 \\
174.74\end{array}$ \\
\hline USUK & $\begin{array}{l}\text { Random walk } \\
\text { RW-0 mean } \\
\text { Forward rate } \\
\text { Markov model }\end{array}$ & $\begin{array}{l}44.54 \\
41.46 \\
45.24 \\
46.11\end{array}$ & $\begin{array}{r}95.86 \\
81.70 \\
97.45 \\
103.91\end{array}$ & $\begin{array}{l}190.46 \\
128.23 \\
189.13 \\
182.48\end{array}$ \\
\hline USWG & $\begin{array}{l}\text { Random walk } \\
\mathrm{RW}-0 \text { mean } \\
\text { Forward rate } \\
\text { Markov model }\end{array}$ & $\begin{array}{l}50.09 \\
50.27 \\
48.99 \\
46.56\end{array}$ & $\begin{array}{r}100.13 \\
100.94 \\
98.13 \\
87.26\end{array}$ & $\begin{array}{l}168.53 \\
171.42 \\
162.07 \\
137.70\end{array}$ \\
\hline $\mathrm{JACA}$ & $\begin{array}{l}\text { Random walk } \\
\text { RW-0 mean } \\
\text { Forward rate } \\
\text { Markov model }\end{array}$ & $\begin{array}{l}47.36 \\
46.17 \\
47.43 \\
52.39\end{array}$ & $\begin{array}{r}97.54 \\
91.70 \\
98.58 \\
120.04\end{array}$ & $\begin{array}{l}160.30 \\
120.27 \\
167.62 \\
175.09\end{array}$ \\
\hline JAFR & $\begin{array}{l}\text { Random walk } \\
\text { RW-0 mean } \\
\text { Forward rate } \\
\text { Markov model }\end{array}$ & $\begin{array}{l}28.68 \\
25.94 \\
26.63 \\
24.96\end{array}$ & $\begin{array}{l}82.03 \\
65.08 \\
70.82 \\
77.78\end{array}$ & $\begin{array}{l}248.20 \\
168.10 \\
195.54 \\
275.82\end{array}$ \\
\hline JAIT & $\begin{array}{l}\text { Random walk } \\
\text { RW }-0 \text { mean } \\
\text { Forward rate } \\
\text { Markov model }\end{array}$ & $\begin{array}{l}32.49 \\
25.30 \\
28.10 \\
34.77\end{array}$ & $\begin{array}{r}96.88 \\
61.76 \\
77.27 \\
102.29\end{array}$ & $\begin{array}{l}305.37 \\
158.85 \\
221.88 \\
323.13\end{array}$ \\
\hline JASW & $\begin{array}{l}\text { Random walk } \\
\text { RW-0 mean } \\
\text { Forward rate } \\
\text { Markov model }\end{array}$ & $\begin{array}{l}23.17 \\
23.19 \\
25.00 \\
22.86\end{array}$ & $\begin{array}{l}57.91 \\
58.11 \\
65.77 \\
57.97\end{array}$ & $\begin{array}{l}162.68 \\
163.59 \\
184.60 \\
190.80\end{array}$ \\
\hline JAUK & $\begin{array}{l}\text { Random walk } \\
\mathrm{RW}-0 \text { mean } \\
\text { Forward rate } \\
\text { Markov model }\end{array}$ & $\begin{array}{l}23.09 \\
21.06 \\
23.74 \\
22.10\end{array}$ & $\begin{array}{l}55.11 \\
42.79 \\
56.86 \\
53.02\end{array}$ & $\begin{array}{r}145.52 \\
70.72 \\
139.54 \\
163.54\end{array}$ \\
\hline JAWG & $\begin{array}{l}\text { Random walk } \\
\text { RW-0 mean } \\
\text { Forward rate } \\
\text { Markov model }\end{array}$ & $\begin{array}{l}24.85 \\
23.84 \\
25.07 \\
26.79\end{array}$ & $\begin{array}{l}65.03 \\
59.23 \\
65.17 \\
73.99\end{array}$ & $\begin{array}{l}180.53 \\
155.95 \\
175.16 \\
213.97\end{array}$ \\
\hline UKCA & $\begin{array}{l}\text { Random walk } \\
\text { RW-O mean } \\
\text { Forward rate } \\
\text { Markov model }\end{array}$ & $\begin{array}{l}38.23 \\
38.12 \\
38.59 \\
37.08\end{array}$ & $\begin{array}{l}73.72 \\
72.60 \\
75.24 \\
77.71\end{array}$ & $\begin{array}{l}114.44 \\
109.12 \\
128.54 \\
113.00\end{array}$ \\
\hline
\end{tabular}


Table 5

Diebold-Mariano statistics for comparison of mean squared forecast errors (estimated quarterly, 1973:3-1986:1; forecast 1986:2-1991:1).

\begin{tabular}{|c|c|c|c|c|}
\hline \multirow[b]{2}{*}{ Currency } & \multirow[b]{2}{*}{ Model } & \multicolumn{2}{|c|}{ Horizon } & \multirow[b]{2}{*}{4} \\
\hline & & 1 & 2 & \\
\hline USFR & $\begin{array}{l}\mathrm{RW} \text { vs. } \mathrm{RW}-0 \text { mean } \\
\text { Markov vs. RW } \\
\text { Markov vs. RW-0 mean } \\
\text { Markov vs. forward rate }\end{array}$ & $\begin{array}{r}1.11 \\
-0.68 \\
-0.06 \\
-0.15\end{array}$ & $\begin{array}{r}1.70 \\
-0.92 \\
0.23 \\
-0.15\end{array}$ & $\begin{array}{r}1.77 \\
-0.92 \\
0.43 \\
0.08\end{array}$ \\
\hline USIT & $\begin{array}{l}\text { RW vs. RW-0 mean } \\
\text { Markov vs. RW } \\
\text { Markov vs. RW-0 mean } \\
\text { Markov vs. forward rate }\end{array}$ & $\begin{array}{l}1.55 \\
2.27 \\
1.79 \\
1.88\end{array}$ & $\begin{array}{l}2.14 \\
2.51 \\
2.28 \\
2.65\end{array}$ & $\begin{array}{l}2.30 \\
3.58 \\
2.59 \\
3.16\end{array}$ \\
\hline USJA & $\begin{array}{l}\text { RW vs. RW-0 mean } \\
\text { Markov vs. RW } \\
\text { Markov vs. RW-0 mean } \\
\text { Markov vs. forward rate }\end{array}$ & $\begin{array}{r}-0.53 \\
0.86 \\
0.61 \\
0.66\end{array}$ & $\begin{array}{r}-0.60 \\
1.41 \\
0.94 \\
1.04\end{array}$ & $\begin{array}{l}-0.40 \\
-0.18 \\
-0.35 \\
-1.18\end{array}$ \\
\hline USSW & $\begin{array}{l}\text { RW vs. RW-0 mean } \\
\text { Markov vs. RW } \\
\text { Markov vs. RW-0 mean } \\
\text { Markov vs. forward rate }\end{array}$ & $\begin{array}{l}-0.65 \\
-0.74 \\
-0.83 \\
-0.91\end{array}$ & $\begin{array}{l}-0.92 \\
-2.47 \\
-1.46 \\
-2.68\end{array}$ & $\begin{array}{l}-0.79 \\
-3.35 \\
-1.23 \\
-4.47\end{array}$ \\
\hline USUK & $\begin{array}{l}\text { RW vs. RW-0 mean } \\
\text { Markov vs. RW } \\
\text { Markov vs. RW-0 mean } \\
\text { Markov vs. forward rate }\end{array}$ & $\begin{array}{l}0.95 \\
0.22 \\
0.86 \\
0.62\end{array}$ & $\begin{array}{l}1.39 \\
0.41 \\
1.74 \\
0.37\end{array}$ & $\begin{array}{r}1.72 \\
-0.20 \\
1.62 \\
-0.22\end{array}$ \\
\hline USWG & $\begin{array}{l}\text { RW vs. RW-0 mean } \\
\text { Markov vs. RW } \\
\text { Markov vs. RW-0 mean } \\
\text { Markov vs. forward rate }\end{array}$ & $\begin{array}{l}-1.00 \\
-0.86 \\
-0.88 \\
-0.76\end{array}$ & $\begin{array}{l}-1.47 \\
-1.26 \\
-1.31 \\
-1.11\end{array}$ & $\begin{array}{l}-1.43 \\
-0.88 \\
-0.94 \\
-0.76\end{array}$ \\
\hline $\mathrm{JACA}$ & $\begin{array}{l}\text { RW vs. RW-0 mean } \\
\text { Markov vs. RW } \\
\text { Markov vs. RW-0 mean } \\
\text { Markov vs. forward rate }\end{array}$ & $\begin{array}{l}0.27 \\
0.68 \\
0.78 \\
0.68\end{array}$ & $\begin{array}{l}0.41 \\
1.13 \\
1.16 \\
0.98\end{array}$ & $\begin{array}{l}0.84 \\
0.54 \\
1.52 \\
0.22\end{array}$ \\
\hline JAFR & $\begin{array}{l}\text { RW vs. } R W-0 \text { mean } \\
\text { Markov vs. RW } \\
\text { Markov vs. RW }-0 \text { mean } \\
\text { Markov vs. forward rate }\end{array}$ & $\begin{array}{r}0.65 \\
-0.65 \\
-0.18 \\
-0.35\end{array}$ & $\begin{array}{r}0.97 \\
-0.31 \\
0.93 \\
0.63\end{array}$ & $\begin{array}{l}1.04 \\
1.06 \\
1.34 \\
1.94\end{array}$ \\
\hline JAIT & $\begin{array}{l}\text { RW vs. RW-0 mean } \\
\text { Markov vs. RW } \\
\text { Markov vs. RW } 0 \text { mean } \\
\text { Markov vs. forward rate }\end{array}$ & $\begin{array}{l}1.14 \\
2.01 \\
1.33 \\
1.55\end{array}$ & $\begin{array}{l}1.36 \\
1.20 \\
1.57 \\
2.24\end{array}$ & $\begin{array}{l}1.27 \\
1.44 \\
1.42 \\
2.24\end{array}$ \\
\hline JASW & $\begin{array}{l}\text { RW vs } R W-0 \text { mean } \\
\text { Markov vs. RW } \\
\text { Markov vs. RW-0 mean } \\
\text { Markov vs. forward rate }\end{array}$ & $\begin{array}{l}-0.25 \\
-0.13 \\
-0.14 \\
-0.79\end{array}$ & $\begin{array}{r}-0.46 \\
0.01 \\
-0.02 \\
-0.68\end{array}$ & $\begin{array}{r}-0.46 \\
0.82 \\
0.82 \\
0.18\end{array}$ \\
\hline JAUK & $\begin{array}{l}\text { RW vs. RW-0 mean } \\
\text { Markov vs. RW } \\
\text { Markov vs. RW-0 mean } \\
\text { Markov vs. forward rate }\end{array}$ & $\begin{array}{r}0.52 \\
-0.37 \\
0.23 \\
0.09\end{array}$ & $\begin{array}{r}0.90 \\
-0.37 \\
0.71 \\
-0.53\end{array}$ & $\begin{array}{l}1.66 \\
1.67 \\
1.83 \\
2.20\end{array}$ \\
\hline JAWG & $\begin{array}{l}\text { RW vs. RW }-0 \text { mean } \\
\text { Markov vs. RW } \\
\text { Markov vs. RW }-0 \text { mean } \\
\text { Markov vs. forward rate }\end{array}$ & $\begin{array}{l}0.67 \\
1.16 \\
1.08 \\
0.70\end{array}$ & $\begin{array}{l}0.93 \\
1.72 \\
1.50 \\
1.14\end{array}$ & $\begin{array}{l}0.92 \\
1.75 \\
1.39 \\
1.21\end{array}$ \\
\hline UKCA & $\begin{array}{l}\text { RW vs. } R W-0 \text { mean } \\
\text { Markov vs. RW } \\
\text { Markov vs. RW-0 mean } \\
\text { Markov vs. forward rate }\end{array}$ & $\begin{array}{r}0.09 \\
-0.24 \\
-0.22 \\
-0.48\end{array}$ & $\begin{array}{l}0.27 \\
0.42 \\
0.75 \\
0.29\end{array}$ & $\begin{array}{r}0.36 \\
-0.10 \\
0.21 \\
-1.02\end{array}$ \\
\hline
\end{tabular}


dollar/lira. At the four-quarter horizon, we can reject the null of no difference in mean squared error at the 5 percent level only for the dollar/lira, and at the 10 percent level for the dollar/French franc, dollar/pound and yen/pound. In general, there is no significant difference between the forecasting ability of the random walk with drift and the random walk without drift models.

Table 6 allows us to check whether the random walk with drift model gets the dircetion of change correct more than half the time. Since the zero-drift random walk predicts no change, this is, in a sense, another check of the relative forecasting ability of the two specifications. The random walk with drift correctly forecasts the direction of change more than half the time for the dollar/yen, dollar/Swiss franc, dollar/mark, yen/French franc, yen/lira, yen/pound and yen/mark. At the one-quarter horizon there are 260 forecasts across the 13 exchange rates. The random walk with drift forecasts the direction correctly about half the time - 132. If we can consider each of those forecasts to be independent of the other, then clearly the random walk with drift is not significantly better than a coin toss at forecasting the exchange rate. The same is true at the other horizons - it forecasts correctly 126 out of 247 two-quarter-ahead forecasts and 110 out of 221 four-quarter-ahead forecasts.

\section{Forecasts from Markov model}

Table 4 also examines the mean squared error for out-of-sample forecasts for the Markov model. The model is estimated through the first quarter of 1986, and the forecast errors are calculated for the five-year period from the second quarter of 1986 to the first quarter of 1991.

First, consider the comparison of the forecasts of the segmented trend to the random walk with drift. The segmented trend model improves on the random walk in only about half of the cases. For the one-quarter-ahead forecasts, the segmented trends model does better for seven of the 13 exchange rates. It outforecasts the random walk with drift for five exchange rates at the two-quarter horizon, and six at the four-quarter horizon. Inspection of table 4 reveals that there are sometimes large differences in the mean squared forecast errors for the two models, but not consistently favoring one of the models. Table 5 presents the Diebold-Mariano statistics. Most of the differences in mean squared error are not significant. There is only one currency for which the Markov model does significantly better (the dollar/Swiss franc) and only a few for which the random walk does significantly better at any horizon.

The performance of the segmented trends model against the forward rate is quite similar - each wins the forecasting contest about half the time. The Markov model does significantly better for the dollar/Swiss franc, and the 
Table 6

Count of correct forecast of direction of change (estimated quarterly, 1973:3-1986:1; forecast 1986:2-1991:1).

\begin{tabular}{|c|c|c|c|c|}
\hline \multirow[b]{2}{*}{ Currency } & \multirow[b]{2}{*}{ Model } & \multicolumn{3}{|c|}{$\begin{array}{l}\text { Horizon } \\
\text { (number of forecast periods) }\end{array}$} \\
\hline & & $\begin{array}{l}1 \\
(20)\end{array}$ & $\stackrel{2}{(19)}$ & $\begin{array}{l}4 \\
(17)\end{array}$ \\
\hline USFR & $\begin{array}{l}\text { Random walk } \\
\text { Forward rate } \\
\text { Markov model }\end{array}$ & $\begin{array}{r}8 \\
6 \\
13\end{array}$ & $\begin{array}{r}5 \\
6 \\
10\end{array}$ & $\begin{array}{r}6 \\
8 \\
10\end{array}$ \\
\hline USIT & $\begin{array}{l}\text { Random walk } \\
\text { Forward rate } \\
\text { Markov model }\end{array}$ & $\begin{array}{l}7 \\
7 \\
7\end{array}$ & $\begin{array}{l}5 \\
5 \\
5\end{array}$ & $\begin{array}{l}6 \\
6 \\
6\end{array}$ \\
\hline USJA & $\begin{array}{l}\text { Random walk } \\
\text { Forward rate } \\
\text { Markov model }\end{array}$ & $\begin{array}{r}10 \\
10 \\
9\end{array}$ & $\begin{array}{r}10 \\
11 \\
9\end{array}$ & $\begin{array}{l}10 \\
10 \\
10\end{array}$ \\
\hline USSW & $\begin{array}{l}\text { Random walk } \\
\text { Forward rate } \\
\text { Markov model }\end{array}$ & $\begin{array}{l}12 \\
10 \\
13\end{array}$ & $\begin{array}{l}13 \\
11 \\
13\end{array}$ & $\begin{array}{r}11 \\
9 \\
11\end{array}$ \\
\hline USUK & $\begin{array}{l}\text { Random walk } \\
\text { Forward rate } \\
\text { Markov model }\end{array}$ & $\begin{array}{r}7 \\
7 \\
11\end{array}$ & $\begin{array}{l}7 \\
7 \\
7\end{array}$ & $\begin{array}{l}6 \\
6 \\
9\end{array}$ \\
\hline USWG & $\begin{array}{l}\text { Random walk } \\
\text { Forward rate } \\
\text { Markov model }\end{array}$ & $\begin{array}{l}11 \\
12 \\
12\end{array}$ & $\begin{array}{l}13 \\
12 \\
12\end{array}$ & $\begin{array}{r}12 \\
11 \\
9\end{array}$ \\
\hline JACA & $\begin{array}{l}\text { Random walk } \\
\text { Forward rate } \\
\text { Markov model }\end{array}$ & $\begin{array}{l}10 \\
10 \\
11\end{array}$ & $\begin{array}{l}9 \\
9 \\
9\end{array}$ & $\begin{array}{l}7 \\
7 \\
7\end{array}$ \\
\hline JAFR & $\begin{array}{l}\text { Random walk } \\
\text { Forward rate } \\
\text { Markov model }\end{array}$ & $\begin{array}{l}13 \\
13 \\
13\end{array}$ & $\begin{array}{l}12 \\
12 \\
11\end{array}$ & $\begin{array}{l}9 \\
8 \\
8\end{array}$ \\
\hline JAIT & $\begin{array}{l}\text { Random walk } \\
\text { Forward rate } \\
\text { Markov model }\end{array}$ & $\begin{array}{l}13 \\
13 \\
13\end{array}$ & $\begin{array}{l}12 \\
12 \\
12\end{array}$ & $\begin{array}{l}8 \\
8 \\
8\end{array}$ \\
\hline JASW & $\begin{array}{l}\text { Random walk } \\
\text { Forward rate } \\
\text { Markov model }\end{array}$ & $\begin{array}{r}8 \\
5 \\
12\end{array}$ & $\begin{array}{l}9 \\
3 \\
9\end{array}$ & $\begin{array}{l}9 \\
4 \\
8\end{array}$ \\
\hline JAUK & $\begin{array}{l}\text { Random walk } \\
\text { Forward rate } \\
\text { Markov model }\end{array}$ & $\begin{array}{l}11 \\
11 \\
11\end{array}$ & $\begin{array}{r}11 \\
11 \\
9\end{array}$ & $\begin{array}{l}11 \\
11 \\
11\end{array}$ \\
\hline JAWG & $\begin{array}{l}\text { Random walk } \\
\text { Forward rate } \\
\text { Markov model }\end{array}$ & $\begin{array}{r}13 \\
9 \\
11\end{array}$ & $\begin{array}{r}12 \\
7 \\
11\end{array}$ & $\begin{array}{l}7 \\
5 \\
6\end{array}$ \\
\hline UKCA & $\begin{array}{l}\text { Random walk } \\
\text { Forward rate } \\
\text { Markov model }\end{array}$ & $\begin{array}{r}9 \\
8 \\
11\end{array}$ & $\begin{array}{r}8 \\
8 \\
11\end{array}$ & $\begin{array}{r}8 \\
5 \\
11\end{array}$ \\
\hline
\end{tabular}


forward rate has a significantly lower mean squared error for the dollar/lira and yen/lira.

Generally, the random walk with zero drift outperforms all other models in terms of mean squared forecast errors. For example, in the four-quarterahead forecasting contest, the zero-drift random walk wins nine of the 13 contests (the segmented trend wins three, and the random walk with trend wins one). At a one-quarter horizon, the zero-drift random walk outperforms the segmented trends model for seven of the 13 exchange rates, and at the other horizons for ten of the exchange rates. However, the variance of the forecast errors is quite large. Hence, by the Diebold-Mariano statistics, the zero-drift random walk significantly outperforms the segmented trends model only for the dollar/lira rate.

Table 6 reports the count of how many times each model forecasted in the correct direction. Clearly, the zero-drift random walk does not belong in this comparison. An analogy to the no-change model in this case would be the coin-toss model.

In the five-year post-sample period, there are 20 quarters to predict. For all but two of the currencies, the segmented trend gets the direction correct more than half of the time. (It misses for the dollar/lira and dollar/yen.) Out of the 260 one-quarter-ahead forecasts, the Markov model forecasts the direction correctly 147 times. Treating these as independent forecasts, the null hypothesis that the model can predict direction no better than a coin toss can be rejected with $p$-value of 1.7 percent.

The random walk with drift and the forward rate do not do nearly so well at the one-quarter-ahead horizon. The random walk model gets the direction correct more than half of the time for only six currencies, while the forward rate achieves this level for only five currencies. The random walk gets the direction correct for 132 out of 260 forecasts, and the forward rate for 121 out of 260 forecasts.

The results are not as impressive at the two- and four-quarter horizons, although they still favor the Markov model. At both horizons, the Markov model gets the direction of change right more than half the time: 128 out of 247 two-quarter-ahead forecasts, and 114 out of 221 four-quarter-ahead forecasts. The $p$-values for these outcomes, assuming independence of all of the forecasts, are 0.283 and 0.319 , respectively. It also outperforms the random walk (126 correct at the two-quarter horizon, and 110 at the fourquarter horizon) and the forward rate (114 and 98).

So, when the size of the forecast error is de-emphasized, the segmented trends model seems more attractive.

\section{Conclusions}

The results of this paper indicate that the Markov switching model does 
not provide particularly good forecasts of exchange rates. The forecasts generated from this model do not generally have lower mean squared error than a random walk (with or without drift) or the forward exchange rate. There is weak evidence that the segmented trends model outperforms its rivals in predicting the direction of change of the exchange rate. All of this evidence comes in spite of the fact that the Markov model significantly outperforms generalized versions of the random walk in-sample.

The zero-drift random walk has done quite well in out-of-sample forecasting contests. It was the winner in Meese and Rogoff's (1983) contest between exchange rate models, and in Diebold and Nason's (1990) test of the forecasting ability of non-linear models. However neither of those papers used the Diebold-Marano statistic to test the significance of the difference in forecasting performance. The more recent study of Chinn and Meese (1992) finds that models that include an error-correction term significantly outperform the no-change hypothesis at longer horizons. ${ }^{1}$

If there are long swings in the exchange rate it might not be too surprising that the Markov model performs well in terms of getting the direction of change corrcet. That is because there will tend to be runs in onc dircction and then the other in changes in the exchange rate. For these exchange rates, the runs do not have to persist for a long time before the Markov model concludes that the state has shifted. Hence, it will miss the direction of change for a short period of time around the date at which the regimes shift, but will tend to get the direction of change correct during long periods of time in which the exchange rate drifts in one direction.

Even though this paper examines many currencies, there is a sense in which the out-of-sample forecast performance of the models may be closely related. The Louvre accord of March 1987 seems to have stabilized all exchange rates. As it happens, this accord comes just one year after the end of our estimation period. If there was a regime switch at this point to a new state that is characterized by low variances and not much drift in exchange rates, the Markov model estimated during our sample would not perform well out-of-sample. While a change in regime is bad news for most models, it is exactly in the spirit of the Markov switching model. Perhaps the Markov model will perform better in the future, allowing for a third state.

\footnotetext{
'Mark (1992) finds similar results at long horizons, but does not include a measure of the significance of out-of-sample performance results.
}

\section{References}

Chinn, M. and R. Meese, 1992, Banking on currency forecasts: How predictable is change in money?, University of California, Santa Cruz.

Diebold, F.X. and R.S. Mariano, 1991, Comparing predictive accuracy I: An asymptotic test, Federal Reserve Bank of Minneapolis, Discussion Paper no. 52. 
Diebold, F.X. and J.A. Nason, 1990, Nonparametric exchange rate prediction, Journal of International tconomics 28, 315-332.

Engel, C., 1992, Can the Markov switching model forecast exchange rates?, National Bureau of Economic Research, Working Paper no. 4210.

Fngel, C.M. and J.D. Hamilton, 1990, Long swings in the dollar: Are they in the data and do markets know it?, American Economic Review 80, 689-713.

Hamilton, J.D., 1989, A new approach to the economic analysis of nonstationary time series and the business cycle, Econometrica 57, 357-384.

Hamilton, J.D., 1990, Analysis of time series subject to changes in regime, Journal of Econometrics 45, 39-70.

Hamilton, J.D., 1991, Estimation, inference, and forecasting of time series subject to changes in regime, manuscript, University of Virginia.

Leitch, G. and J.E. Tanner, 1991, Economic forecast evaluation: Profits versus the conventional error measures, American Economic Review 81, 580-590.

Mark, N.C., 1992, Exchange rates and fundamentals: Evidence on long-horizon predictability and overshooting, Working Paper, Ohio State University.

Meese, R. and K. Rogoff, 1983, Empirical exchange rate models of the seventies: Do they fit out of sample?, Journal of International Economics 14, 3-24.

West, K.D., H.J. Edison and D. Cho, 1992, A utility based comparison of some models of exchange rate volatility, Working Paper, University of Wisconsin. 